\title{
Fas/FasL promoter gene polymorphism in patients with rheumatoid arthritis
}

\author{
S̨. Kobak ${ }^{1}$, A. Berdeli ${ }^{2}$ \\ 'Department of Rheumatology, Siifa University, Izmir, Turkey; \\ ${ }^{2}$ Department of Pediatrics, Laboratory of Molecular Medicine, Ege University, Izmir, Turkey
}

\begin{abstract}
SUMMARY
Objectives. Fas/FasL is significantly involved in the pathogenesis of rheumatoid arthritis (RA). Fas/FasL gene polymorphism may be associated with susceptibility to rheumatoid arthritis and disease severity.

Aim. To investigate the Fas $670 \mathrm{G} / \mathrm{A}$ and FasL $843 \mathrm{C} / \mathrm{T}$ genotype and allele frequency in patients with RA, and determine its potential association with susceptibility to the disease and the clinical parameters.

Methods. One hundred and one patients with RA and 105 healthy control subjects were enrolled in the study. Fas $670 \mathrm{~A} / \mathrm{G}$ and FasL 843C/T genotype polymorphism was investigated by PCR-RFLP. Chi-square test was used for determining the genotype distribution and the allele incidence.

Results. There was no statistically significant difference between the patients with RA and the healthy subjects with respect to Fas-670 A/G and FasL-843C/T genotype distribution and allele frequency ( $>0.05)$. While there was no statistically significant difference in disease severity and various clinical parameters, a correlation was detected between Fas-670 polymorphism and anti-CCP antibody and anemia $(\mathrm{P}<0.01$ and $\mathrm{P}<0.03$, respectively).

Conclusions. Fas-670A/G and FasL-843C/T promoter gene polymorphisms are not considered to represent a major genetic risk factor for RA susceptibility and disease severity. However, based on these results, Fas-670 promoter polymorphism may modulate anti-CCP antibody synthesis and response in patients with rheumatoid arthritis.
\end{abstract}

Key words: Rheumatoid arthritis, Fas/FasL, gene polymorphism, association, manifestations.

Reumatismo, 2012; 64 (6): 374-379

\section{INTRODUCTION}

$\mathrm{R}$ heumatoid arthritis (RA) is a chronic, multisystemic, autoimmune disease with no well-established etiology, which manifests itself with synovial hyperplasia, articular cartilage and bone destruction. In RA synovium, pannus formation occurs as a result of permanent and abnormal synoviocytes and various inflammatory cell proliferations $(1,2)$. The cause of this chronic inflammation is not yet clear; however, one of the basic, major hypothesis is inadequate apoptosis $(3,4)$. Many various molecules and receptors have been defined in the regulation of cell apoptosis; however, Fas-Fas ligand death receptor pathway is significantly involved in the pathogenesis of RA (5). Fas(CD95) is a molecule that is expressed on the cell surface and initiates the signaling of death after binding its ligand (FasL). While Fas is expressed in many cells, FasL is expressed in exclusive regions such as the active $\mathrm{T}$ cells, the natural killer cells, the tumor cells and the eye. The Fas-FasL interaction accounts for the T-lymphocyte activation-mediated cell death, the natural killer cell and the T-lymphocyte cytotoxicity. In addition, they play an important role in lymphocyte homeostasis $(6,7)$; in vitro studies demonstrated a high level of Fas/FasL expression and secondary Fas-mediated susceptibility to apoptosis in synoviocytes, synovial T cells and macrophages (8). Increased intra-synovial and/or serum sFas prevents the apoptosis of synoviocytes. Cytokines of stromal cell origin (e.g., TGF-b, TNF-alpha, IL-1, FGF) protect the RA synoviocytes against Fas-mediated apoptosis $(9,10)$. RA T-lymphocytes are protected against apoptosis as a result of close connection with the fibroblast-like synoviocytes. In addition, RA synovial macrophages and fibroblasts pro- 
vide the up-regulation of the FLIP and the sentrin (11-13). At the same time, RA inhibits the nitric oxide (NO), caspase-3 and stromelysin-1 $(14,15)$. Different intra- and extracellular pathways lead to impairment of Fas-mediated apoptosis in the RA joint. Fas and FasL play a significant role in the pathogenesis of various autoimmune diseases such as RA and SLE (16). The impaired mechanisms of apoptosis and the increased Fas gene expression may result in a number of genetic disorders. An association was demonstrated between the Fas gene promoter polymorphism and the pathogenesis of diseases such as SLE and multiple sclerosis (17). In the Fas gene promoter region, 2 single nucleotide polymorphisms were commonly demonstrated, namely -1377 G-A and -670 A-G. The biological impact of these polymorphisms is not well-established; while Fas-1377 polymorphism probably binds the transcription factor SP-1 sequences, Fas-670 is associated with the nuclear transcription factor GAS. Based on our hypothesis, the genetic variations occurring in the Fas/FasL promoter region may be significantly involved in the pathogenesis of RA by affecting apoptosis. The current study was designed to investigate the Fas/FasL promoter gene polymorphism, and demonstrate the association with disease activity, clinical and laboratory findings.

\section{MATERIALS AND METHODS}

One hundred and one patients with RA under follow-up at a single center and 105 age and sex matched healthy control individuals were enrolled in the study. After obtaining a consent from all RA patients and the healthy subjects, peripheral blood samples were drawn into Na-EDTA containing tubes and stored at $-80^{\circ} \mathrm{C}$. The study was approved by the Regional Committee of Ethics.

\section{Patients}

One hundred and one (86 females) patients diagnosed with RA according to ACR classification criteria were enrolled in the study.
Table I - Demographic and clinical features of RA patients of the current study.

\begin{tabular}{|l|l|}
\hline Age (median) & $55.8(19-72)$ \\
\hline Disease duration (years) & 8.3 \\
\hline Sex (f/m) & $86 / 15$ \\
\hline Tenosynovitis & $60(59.4 \%)$ \\
\hline Lung involvement & $7(6.9 \%)$ \\
\hline Sicca (s/m) & $41(40.6 \%)$ \\
\hline Rheumatoid nodule & $5(5.0 \%)$ \\
\hline Hand deformity & $24(23.8 \%)$ \\
\hline Anemia & $51(50.5 \%)$ \\
\hline DAS28 & \\
$>5.1$ & $50(49.5 \%)$ \\
\hline $3.2-5.1$ & $15(14.9 \%)$ \\
$<3.2$ & $36(35.6 \%)$ \\
\hline Amiloidosis & $1(1 \%)$ \\
\hline Felty (s/m) & $1(1 \%)$ \\
\hline RF positivity & $90(89.1 \%)$ \\
\hline Anti-CCP positivity & $73(72.3 \%)$ \\
\hline
\end{tabular}

$\mathrm{RA}=$ rheumatoid arthritis.

The mean patient age was 55.8 years, the mean disease duration was 8.3 years. The demographic and clinical features of RA patients are presented in Table I.

\section{Genomic DNA preparation}

Genomic DNA was extracted from EDTA-anticoagulated whole blood samples using a commercially available genomic DNA purification kit (Nucleospin Blood L, Macherey-Nagel, Germany) following manufacturer's instructions. DNA concentration used by the PicoGreen dsDNA quantitation kit (Molecular Probes Inc., Eugene, OR, USA) using manufacturer's instructions which were diluted as $100 \mathrm{ng} / \mu \mathrm{L}$.

PCR-restriction fragment length polymorphism (PCR-RFLP) genotyping for the Fas gene 670A/G polymorphism

The Fas-670A/G polymorphism was described previously with some minor modifications. Briefly, amplification was carried out on a GeneAmp PCR System 9700 (PE Applied Biosystems, Foster City, CA, USA) in a $25 \mu \mathrm{L}$ reaction mixture in 0.2 $\mathrm{mL}$ thin-wall PCR strip tubes (Axygen Scientific, Inc., Union City, CA, USA) containing $1 \mu \mathrm{L}$ genomic DNA solution, GeneAmp Gold Buffer (15 mmol/l Tris$\mathrm{HCl}, \mathrm{pH}$ 8.0, $50 \mathrm{mmol} / \mathrm{l} \mathrm{KCl}$; PE Applied 
Biosystems), $1.5 \mathrm{mmol} \mathrm{MgCl}$, $50 \mu \mathrm{mol} / \mathrm{l}$ each of the deoxyGTP (dGTP), deoxyATP (dATP), deoxythymidine triphosphate (dTTP), and deoxyCTP (dCTP) (Promega, Madison, WI), 25 pmol each forward and reverse primers and 1.0U AmpliTaq Gold polymerase (PE Applied Biosystems). The cycling conditions comprised a hot start at $95^{\circ} \mathrm{C}$ for $10 \mathrm{~min}$, followed by 35 amplification cycles at $95^{\circ} \mathrm{C}$ for $45 \mathrm{~s}, 62^{\circ} \mathrm{C}$ for $45 \mathrm{~s}$, and $72^{\circ} \mathrm{C}$ for $45 \mathrm{~s}$, and a final extension at $72^{\circ} \mathrm{C}$ for $7 \mathrm{~min}$.

\section{Primers used for PCR-RFLP}

For Fas $-670 \mathrm{~A} / \mathrm{G}$ polymorphism forward PCR-RFLP primer was 5'-CTA CCT AAG AGC TAT CTA CCG TTC-3' and reverse PCR-RFLP primer was 5' -GGC TGT CCA TGT TGT GGC TGC-3', respectively.

\section{Digest conditions}

Amplified 331 bp PCR product $(3 \mu \mathrm{L})$ was digested in a $10-\mu \mathrm{cL}$ final reaction volume using $1 \mu \mathrm{cL}$ of Reaction Buffer 2 and 5 units of MvaI restriction enzyme (New England Biolabs, Beverly, MA, USA), at $37^{\circ} \mathrm{C}$ overnight. Controls of known genotype were included for every set of digestions carried out. After digestion allele $\mathrm{G}$ yielded three fragments of 99,188 , and 44 bp, whereas allele A yielded two fragments of 99 and $232 \mathrm{bp}$. Digested fragments were separated on $3 \%$ agarose gels and visualized after ethidium bromide staining in the BioDoc-It System (UVP, Upland, CA, USA) Biolmaging systems.

\section{PCR-RFLP genotyping for the $-843 C / T$ polymorphism of FasL gene}

Genomic DNA was amplified using PCR carried out on a Gene-Amp PCR System 9700 (PE Applied Biosystems) in a 25 $\mu \mathrm{L}$ reaction mixture in $0.2 \mathrm{~mL}$ thin-wall PCR strip tubes (Axygen Scientific, Inc.) containing $2 \mu \mathrm{L}$ genomic DNA solution, GeneAmp Gold Buffer (15 mmol/l Tris$\mathrm{HCl}, \mathrm{pH}$ 8.0, $50 \mathrm{mmol} / \mathrm{l} \mathrm{KCl}$; PE Applied Biosystems), $1.5 \mathrm{mmol} \mathrm{MgCl} 2,50 \mu \mathrm{mol} / \mathrm{l}$ each of the dGTP, dATP, dTTP, and dCTP (Promega, Madison, WI, USA), 5 pmol each forward and reverse primers and 1.5 U AmpliTaq Gold polymerase (PE Ap- plied Biosystems). The cycling conditions comprised a hot start at $95^{\circ} \mathrm{C}$ for $10 \mathrm{~min}$, followed by 35 amplification cycles at $95^{\circ} \mathrm{C}$ for $30 \mathrm{~s}, 45^{\circ} \mathrm{C}$ for $30 \mathrm{~s}$, and $72^{\circ} \mathrm{C}$ for $30 \mathrm{~s}$, and a final extension at $72^{\circ} \mathrm{C}$ for 10 min. Forward (5'-CAA TGA AAA TGA ACA CAT TG-3') and reverse (5'-CCC ACT TTA GAA ATT AGA TC-3') primers were used according to the published sequence (Genbank accession number AF027385).

\section{Digest conditions}

Amplified 114 bp PCR product $(7 \mu \mathrm{L})$ was digested in a $20-\mu \mathrm{cL}$ final reaction volume using $2 \mu \mathrm{cL}$ of Reaction Buffer 2 and 5 units of DraIII restriction enzyme (New England Biolabs, Beverly, MA, USA), at $37 \mathrm{C} 3 \mathrm{~h}$. After digestion allele $\mathrm{T}$ yielded two fragments of 98 and $16 \mathrm{bp}$, whereas allele C wasn't digested and yielded $114 \mathrm{bp}$. Digested electrophoresis on gels containing a mixture of 1.5\% Agarose (Sigma, St. Louis, MO, USA) and 1.5\% NuSieve GTG (BMA, Rockland, ME, USA) was run for $1.5 \mathrm{~h}$ at $70 \mathrm{~V}$ and visualized after ethidium bromide staining in the BioDoc-It System Biolmaging systems (UVP).

\section{Statistical analysis}

The Hardy-Wainberg principle was used to test whether the patient and the control groups were balanced. Then, using the $\chi^{2}$-test, the patients and the subjects genotype distribution and allele frequency were evaluated. The association of the genotype and allele frequency with the disease parameters was assessed by $\chi^{2}$-test. The statistical analysis was performed using SPSS and $\mathrm{P}<0.05$ was considered statistically significant.

\section{RESULTS}

\section{Fas-670 G/A polymorphism}

Fas/670 genotype distribution and the allele frequency were detected to be similar between the RA patient group and the healthy subject group (Tab. II). GA genotype and $\mathrm{A}$ allele were more frequent in both groups. Whilst no association among 
Fas gene polymorphism, the disease severity and certain clinical findings was determined, there was a statistically significant difference with anemia and anti-CCP antibodies $(\mathrm{P}<0.01, \mathrm{P}<0.03$, respectively) (Tab. III).

\section{Fas L-843 C/T polymorphism}

FasL/844 genotype distribution and the allele frequency did not show a statistically significant difference between the RA patients and the healthy subject group (Tab. IV). CT genotype was more frequent in both groups (39.6\% and $41.6 \%)$. There was no statistically significant difference in FasL gene polymorphism and the disease severity and the clinical parameters (Tab. V).

Table II - Fas/670 genotype distribution and allele frequencies of RA patients and healthy controls.

\begin{tabular}{|l|l|l|l|l|l|}
\hline Groups & Genotypes & \multicolumn{4}{l|}{ Alleles } \\
\hline & GG & GA & AA & G & A \\
\hline RA & $24(24.7 \%)$ & $50(48.5 \%)$ & $27(26.7 \%)$ & $99(98 \%)$ & $103(12 \%)$ \\
\hline Control & $14(13.3 \%)$ & $52(49.5 \%)$ & $39(37.2 \%)$ & $80(76.1 \%)$ & $130(123 \%)$ \\
\hline
\end{tabular}

$\mathrm{RA}=$ rheumatoid arthritis.

Table III - Clinical and laboratory analysis of the RA patients according to the Fas 670 genotypes.

\begin{tabular}{|c|c|c|c|c|}
\hline & \multicolumn{3}{|c|}{ Fas-670 Genotypes } & \multirow[b]{2}{*}{$\mathrm{P}$} \\
\hline & $\mathrm{AA}(\mathrm{N}=27)$ & $\mathrm{GA}(\mathrm{N}=49)$ & $\mathrm{GG}(\mathrm{N}=25)$ & \\
\hline Tenosynovitis & 16 & 26 & 18 & 0.169 \\
\hline Lung involvement & 4 & 1 & 2 & 0.102 \\
\hline Sicca $(\mathrm{s} / \mathrm{m})$ & 13 & 19 & 9 & 0.646 \\
\hline Rheumatoid nodule & 4 & 1 & 0 & 0.021 \\
\hline Hand deformity & 5 & 12 & 7 & 0.671 \\
\hline Anemia & 16 & 18 & 17 & 0.010 \\
\hline DAS28 $>5.1$ & 9 & 28 & 13 & 0.219 \\
\hline RF positivity & 24 & 43 & 23 & 0.445 \\
\hline Anti-CCP positivity & 19 & 33 & 21 & 0.030 \\
\hline
\end{tabular}

$\mathrm{RA}=$ rheumatoid arthritis.

Table IV - FasL/843 genotype distribution and allele frequencies of RA patients and healthy controls.

\begin{tabular}{|l|l|l|l|l|l|}
\hline Groups & Genotypes & Alleles \\
\hline & CC & CT & TT & C & T \\
\hline RA $(n=105)$ & $30(29.7 \%)$ & $40(39.6 \%)$ & $31(30.7 \%)$ & 100 & 102 \\
\hline Controls $(n=96)$ & $33(34.5 \%$ & $40(41.6 \%)$ & $23(23.9 \%)$ & 106 & 86 \\
\hline
\end{tabular}

$\mathrm{RA}=$ rheumatoid arthritis.

Table V - Clinical and laboratory analysis of the RA patients according to the FasL-843 genotypes.

\begin{tabular}{|l|l|l|l|l|}
\hline & FasL-843 Genotypes & \\
\hline & $\mathrm{CC}(\mathrm{N}=30)$ & $\mathrm{CT}(\mathrm{N}=40)$ & $\pi(\mathrm{N}=31)$ & $\mathrm{P}$ \\
\hline Tenosynovitis & 20 & 25 & 15 & 0.305 \\
\hline Lung involvement & 0 & 3 & 4 & 0.137 \\
\hline Sicca $(\mathrm{s} / \mathrm{m})$ & 14 & 13 & 14 & 0.404 \\
\hline Rheumatoid nodule & 2 & 0 & 3 & 0.154 \\
\hline Hand deformity & 8 & 8 & 8 & 0.770 \\
\hline Anemia & 14 & 21 & 16 & 0.880 \\
\hline DAS28 $>5.1$ & 12 & 24 & 14 & 0.199 \\
\hline RF positivity & 29 & 36 & 25 & 0.130 \\
\hline Anti-CCP positivity & 25 & 28 & 20 & 0.239 \\
\hline
\end{tabular}

$\mathrm{RA}=$ rheumatoid arthritis 


\section{DISCUSSION}

Rheumatoid arthritis is a systemic, autoimmune disease mediated by various inflammatory cells that leads to synovial tissue hyperplasia, articular cartilage and bone destruction. Although its pathogenesis is not well-established, the potential role of certain genetic factors is discussed. Certain non-HLA genes as well as the known conventional HLA-gene association are considered to be potentially involved in the pathogenesis (18).

Apoptosis is an important process that provides cell homeostasis under physiological conditions. Impairment in the elimination of autoreactive $\mathrm{T}$ and $\mathrm{B}$ cells may lead to various autoimmune diseases (19). The Fas molecule accounts for the deletion of autoreactive peripheral lymphocytes and is thus significantly involved in the regulation of the immune system. Therefore, Fas, an apoptosis gene may play an important role in the pathogenesis of RA.

Studies demonstrated that synoviocytes and the lymphocytes present in the rheumatoid synovium exhibited Fas expression (20). Based on these findings, Fas-mediated apoptosis may be significantly involved in the regression of synovial hyperplasia. Huang et al. investigated the Fas promoter-670 polymorphism in patients with SLE and RA. Although an increased Mval genotype incidence was detected in 103 Australian patients with RA, SLE patients had the same Mval genotype distribution with the control group.

In addition, AA genotype was more frequent in SLE patients with photosensitivity and oral ulcer (17). In another study, Fas-670 promoter gene polymorphism was associated with development of antiRNP antibodies in patients with SLE (21). Coakley et al. investigated the correlation between RA and Felty syndrome or large granular lymphocyte leukemia and the Fas promoter gene polymorphism (22). There was no significant difference between the groups in genotype and allele incidence. No evidence of Fas gene polymorphism that would cause susceptibility to these diseases could be detected. Mullighan et al. investigated the Fas gene promoter polymorphism in patients with primary Sjögren's syndrome (SS) (23). Although there was no difference between the SS and the control group with respect to genotype and allele distribution, 670A allele was more frequent in Ro/La negative patients. These results suggest that the Fas gene expression modulates the Ro/La antibody response in SS patients. Donn et al. investigated whether a polymorphism in the Fas-670 promoter region confers susceptibility to juvenile idiophatic arthritis (JIA). No statistically significant differences were found between the JIA cases and the controls. Similarly no differences were seen between the JIA subgroups, or when the patients were divided on the basis of rheumatoid factor or antinuclear antibody positivity (24).

The present study detected no association between the RA patients and the healthy control subjects with respect to Fas-670 and FasL-843 genotype and allele distribution.

A potential polymorphism in these genes was shown not to cause a susceptibility to the disease. In addition, a potential correlation between the Fas-670 and FasL843 gene polymorphisms and the clinical parameters of the disease was detected. Whilst no correlation was detected for many parameters investigated, there was a statistically significant correlation between the Fas promoter gene -670 gene and anemia and anti-CCP antibody positivity.

These results suggest that the Fas promoter -670 gene modulated anti-CCP antibody synthesis and antibody response in patients with RA. In conclusion, while the present study detected no association between the Fas/FasL promoter gene polymorphism and RA, the Fas promoter -670 polymorphism was detected to be associated with anti-CCP antibody synthesis. The exact role of the Fas promoter -670 polymorphism is not yet well-established, and either the geographical and ethnical distribution of this polymorphism is not known. Multi-center, controlled trials are required to elucidate the significance and the role of the Fas gene polymorphism in different ethnical groups. 


\section{REFERENCES}

1. Feldmann M, Brennan FM, Maini RN. Rheumatoid arthritis. Cell. 1996; 85: 307-10.

2. Firestein GS. Invasive fibroblast-like synoviocytes in rheumatoid arthritis. Passive responders or transformed aggressors? Arthritis Rheum. 1996; 39: 1781-90.

3. Pope RM. Apoptosis as a therapeutic tool in rheumatoid arthritis. Nat Rev Immunol. 2002; 2: 527-35.

4. Kobayashi T, Okamoto K, Kobata T, et al. Apomodulation as a novel therapeutic concept for the regulation of apoptosis in rheumatoid synoviocytes. Curr Opin Rheumatol. 1999; 11: 188-93.

5. Okamoto K, Kobayashi T, Kobata T, et al. Fasassociated death domain protein is a Fas-mediated apoptosis modulator in synoviocytes. Rheumatology. 2000; 39: 471-80.

6. Wallach D, Varfolomeev EE, Malinin NL, et al. Tumor necrosis factor receptor and Fas signaling mechanisms. Ann Rev Immunol. 1999; 17: 331-67.

7. Siegel RM, Chan FK, Chun HJ, Lenardo MJ. The multifaceted role of Fas signaling in immune cell homeostasis and autoimmunity. Nat Immunol. 2000; 1: 469-74.

8. Firestein GS, Yeo M, Zvaifler NJ. Apoptosis in rheumatoid arthritis synovium. J Clin Invest. 1995; 96: 1631-8.

9. Nakajima T, Aono H, Hasunuma T, et al. Apoptosis and functional Fas antigen in rheumatoid arthritis synoviocytes. Arthritis Rheum. 1995; 38: 485-91.

10. Kawakami A, Eguchi K, Matsuoka N, et al. Inhibition of Fas antigen-mediated apoptosis of rheumatoid synovial cells in vitro by transforming growth factor-1. Arthritis Rheum. 1996; 39: 1267-76.

11. Palao G, Santiago B, Galindo M, et al. Downregulation of FLIP sensitizes rheumatoid synovial fibroblasts to Fas-mediated apoptosis. Arthritis Rheum. 2004; 50: 2803-10.

12. Schedel J, Gay RE, Kuenzler P, et al. FLICEinhibitory protein expression in synovial fibroblasts and at sites of cartilage and bone erosion in rheumatoid arthritis. Arthritis Rheum. 2002; 46: 1512-8.

13. Franz JK, Pap T, Hummel KM, et al. Expres- sion of sentrin, a novel antiapoptotic molecule, at sites of synovial invasion in rheumatoid arthritis. Arthritis Rheum. 2000; 43: 599-607.

14. Migita K, Yamasaki S, Kita M, et al. Nitric oxide protects cultured rheumatoid synovial cells from Fas-induced apoptosis by inhibiting caspase-3. Immunology. 2001; 103: 362-7.

15. Matsuno $H$, Yudoh K, Watanabe $Y$, et al. Stromelysin-1 (MMP-3) in synovial fluid of patients with rheumatoid arthritis has potential to cleave membrane bound Fas ligand. J Rheumatol. 2001; 28: 22-8.

16. Itoh $\mathrm{K}$, Hase $\mathrm{H}$, Kojima $\mathrm{H}$, et al. Central role of mitochondria and p53 in Fas-mediated apoptosis of rheumatoid synovial fibroblasts. Rheumatology. 2004; 43: 277-85.

17. Huang QR, Danis V, Lassere M,. Edmonds J, Manolios N. Evaluation of a new Apo-1/Fas promoter polymorphism in rheumatoid arthritis and systemic lupus erythematosus patients. Rheumatology. 1999; 38: 645-51.

18. Muller-Ladner U, Kriegsmann J, Gay RE, Gay $\mathrm{S}$. Oncogenes in rheumatoid arthritis. Rheum Dis Clin North Am. 1995; 21: 675-90.

19. Ogawa N, Dang H, Talal N. Apoptosis and autoimmunity. J Autoimmun. 1995; 8: 1-19.

20. Matsumoto S, Müller LU, Gay RE, Nishioka K, Gay S. Ultrastructural demonstration of apoptosis, Fas and Bcl-2 expression of rheumatoid synovial fibroblasts. J Rheumatol. 1996; 23: $1345-52$.

21. Lee YH, Kim YR, Ji JD, Sohn J, Song GG. Fas promoter -670 polymorphism is associated with development of anti-RNP antibodies in systemic lupus erythematosus. J Rheumatol. 2001; 28: 2008-11.

22. Coakley G, Manolios N, Loughran TP Jr, et al. A Fas promoter polymorphism at position -670 in the encancer region does not confer susceptibility to Felty's and large granular lymphocyte syndromes. Rheumatology 1999; 38: 883-6.

23. Mullighan CG, Heatley S, Lester S, et al. Fas gene promoter polymorphisms in primary $\mathrm{Sjö-}$ gren's syndrome Ann Rheum Dis. 2004; 63: 98-101.

24. Donn R, Zeggini E, Shelley E, et al. Lack of association between juvenile idiopathic arthritis and fas gene polymorphism. J Rheumatol. 2002; 29: 166-8. 